\title{
Belo Apolo: Apaixonado e vingativo
}

\author{
Beautiful Apollo: Passionate and vengeful
}

Fátima Regina Sans Martini ${ }^{1}$

\section{Resumo}

O presente texto narra algumas histórias mitológicas relacionadas ao deus Apolo, filho de Zeus, considerado como o mais belo dos imortais. Ao cruzar as imagens e as histórias sobre um dos personagens mais complexos da Mitologia, dividido entre o bem e o mal, o objetivo é conduzir o leitor à compreensão do tema e o propósito artístico das obras. As fábulas sobre deuses e heróis, assim como as Artes visuais, resultam em amplo conteúdo, por conseguinte, se faz necessário a seleção de pinturas, gravuras e esculturas, inseridas no espaço artístico relevante, compreendido a partir do Renascimento até o Neoclássico, períodos da Idade Moderna em que o artista busca inspiração na arte greco-romana. A metodologia empregada no texto é a investigação histórica, qualitativa e descritiva, apoiada nas obras de: Homero, Hesíodo e Ovídio e, nas Artes visuais com imagens relacionadas às histórias do deus Apolo. Conclui-se que as expectativas na realização da proposição são atendidas com a evolução contínua das questões que se referem aos deuses da mitologia clássica e, como resultado final: um conhecimento que conduz a uma nova atitude em relação à apreciação literária e artística em seus diferentes períodos sociais, culturais e históricos.

Palavras-chave: Literatura. Mitologia. Apolo. Artes visuais.

\begin{abstract}
The present text reports some mythological stories related to the god Apollo, son of Zeus, considered as the most beautiful of the immortals. While cruising the images and the stories about one of the most complex characters of Mythology, torn between good and evil, the goal is to take the reader to understand the topic and the purpose of the artistic works. The fables about gods and heroes, as well as the visual arts, result in extensive content, therefore, it is important to select the paintings, prints and sculptures, inserted into the relevant artistic space, understood from the Renaissance until the Neoclassical, periods of the

\footnotetext{
${ }^{1}$ Mestre em Artes Visuais com Abordagens Teóricas, Históricas e Culturais pela UNESP. Pós-graduação em História da Arte pela FAAP-SP. Professora de Estética e História da Arte Mundial e Brasileira em EAD na Universidade Metropolitana de Santos (UNIMES). Professora de História do Mobiliário; Desenho de Mobiliário e História da Arte na Universidade Católica de Santos. E-mail: fatimartini@yahoo.com.br.
} 
Modern Age in which the artist seeks inspiration from Greco-Roman art. The methodology employed in the text is historical, qualitative and descriptive research, supported in the works of: Homer, Hesiod and Ovid and in the Visual Arts with images related to the stories of the god Apollo. It is concluded that the expectations in the realization of the proposition are answered with the continuous evolution of the questions refer to the gods of classical mythology and, as a final result: a knowledge that leads to a new attitude towards literary and artistic appreciation in their different social, cultural and historical periods.

Keywords: Literature. Mythology. Apollo. Visual Arts.

\section{INTRODUÇÃO}

A Mitologia abrange uma série de histórias provenientes, durante séculos, de crenças, dogmas e, quiçá, de fatos reais. O que se pode afirmar é que, sejam fantasias ou episódios históricos, os textos escritos na Antiguidade e, guardados na memória, servem como fonte de inspiração das representações simbólicas em grandes obras de arte até hoje.

Inúmeras obras sobre deuses, semideuses e heróis são narradas na Antiguidade. Textos teatrais, conhecidos por tragédias gregas e adaptações romanas, interpretam os mitos por intermédio dos mortais. A literatura do período é uma ferramenta fundamental e um espelho, para se perceber o processo histórico das transformações socioculturais que ocorrem na transição da Grécia arcaica para a clássica. O mundo caracterizado pelo misticismo, e as limitações do homem frente aos deuses, se desenvolve em busca de algo novo, porém, não tão compreensível, conquanto as personagens trágicas, quase sempre pagam alto preço por suas escolhas.

As artes visuais também ajudam a explicar o significado dos mitos, assim como esclarece as paixões humanas por meio das esculturas, gravuras e pinturas. A mitologia greco-romana apresentada em todo seu esplendor no período clássico segue a partir do Renascimento, no século XVI, até o século XIX, com outros estilos. Observar o passado com imaginação e julgar à luz da razão. Eis o objetivo da arte literária e das imagens artísticas. 
A metodologia empregada no texto é a investigação histórica, qualitativa e descritiva, apoiada nas obras de: HOMERO (liada e Odisseia, 2015); HESÍODO (Teogonia, 2013) e OVÍDIO (Metamorfoses, 2017) e, nas artes visuais (escultura, gravura e pintura), as quais representam os diferentes estilos artísticos e se relacionam às histórias do deus Apolo.

A partir da introdução o texto expõe um resumo sobre a origem da Mitologia, e segue com a apresentação de Apolo filho de Zeus, o Apolo apaixonado e o deus vingativo.

Assim, cruzando literatura e artes visuais, a humanidade em busca de conhecimento, entende melhor as representações simbólicas, o significado dos mitos e a influência das paixões, compreende a origem dos costumes, aceita o destino muitas vezes cruel, aprende a reconhecer o mal e o bem, ambos intrínsecos e ajustados pela sociedade e ainda, transformam seu próprio ambiente cultural.

\section{A ORIGEM DA MITOLOGIA}

O que conhecemos como a origem da Mitologia, com seus inúmeros detalhes, semelhanças e inacreditáveis assuntos, vem do período denominado de épico, em que se destacam, entre outros, HOMERO (ca. IX-VIII a.C.), autor dos poemas heroicos Miada ${ }^{2}$ e Odisseia ${ }^{3}$, que datam em torno do fim do século IX a.C., em que relata as aventuras dos heróis Aquiles e Odisseu, envolvidos com os deuses e, HESÍODO (ca. VIII-VII a.C.), autor de Teogonia. Em ambos os poemas estão registrados os nomes dos diversos deuses, suas paixões e honrarias.

\footnotetext{
2 História da guerra de Troia e a disputa entre Aquiles e Agamémnon, comandante dos exércitos gregos em Troia. Encerra-se com a morte e o funeral de Heitor, herói troiano.

3 Sequência da líada, a Odisseia relata o regresso de Odisseu, ao final da Guerra de Tróia, uma figura à parte na narrativa da disputa entre gregos e troianos. O herói, extremamente ardiloso, casado com Penélope, filha de Ícaro, depois de destruir a cidade de Tróia, conhece diferentes cidades e costumes. No mar luta pela vida e pelos companheiros, passando pelos mais variados tormentos, até chegar a Ítaca, sua terra natal.
} 
Por volta do século VIII a.C. os diversos dialetos falados nos territórios gregos foram modificados e integrados às práticas sociais, ocasionando, no entanto, lacunas que a arqueologia e a história não conseguiram reconstruir. Dessa forma, por mais pesquisas sobre o assunto, nada se pode afirmar quando nem como os poemas de Homero e os de Hesíodo receberam a primeira redação.

O poema Teogonia, de Hesíodo descreve a origem e a genealogia dos deuses. O poeta segue narrando a história de Zeus como governante do mundo, que tem o poder de unir e manter a existência da humanidade, por meio das uniões sagradas com deusas e mortais.

Sem dúvida, os primeiros textos gregos indicam um estágio primitivo de evolução, em que a magia, os encantamentos, a guerra e o trabalho eram primordiais, atribuindo-se aos salteadores a função de herói. A história de Tróia, em Iliada de Homero, glorifica poeticamente o rapto e a pirataria, no entanto, com as transformações e evolução da sociedade grega, o nobre personagem Heitor, filho do $\mathrm{rei}^{4}$ da cidade murada, é apresentado como valente e generoso.

Já quase no final do século V a.C., os assuntos mitológicos servem de meio para discutir as questões filosóficas e os problemas comuns das diferentes classes sociais, como relações dos sexos, casamento, situação social e doméstica da mulher, em que alguns dos personagens assumem um caráter dúbio. A comédia é incorporada aos festivais dramáticos.

No período Helenístico, os valores humanos se destacam. O interesse por personalidades do povo dá origem ao romance e à comédia humana, com textos mais realistas e a exclusão de sátiras violentas. A Tragicomédia une personagens populares aos deuses, semideuses e mortais, da mitologia.

Na virada do século I, Publios OVÍDIO Naso (43 a.C.- 17 d.C.) transfere para sua poesia a influência de Homero. Um de seus mais conhecidos poemas

\footnotetext{
${ }^{4}$ Rei de Tróia, Príamo é apresentado como idoso, pai de valorosos guerreiros, entre eles, Heitor e o jovem Páris.
} 
é Metamorfoses. Dividido em quinze livros com cerca de doze mil versos em latim abrange a cosmogonia 5 e a etiologia 6 .

Ovídio, em Metamorfoses, confunde ficção e realidade, transforma personagens e deuses mitológicos em animais, plantas, rios e pedras, no princípio dos tempos e chega até seu próprio tempo e de Augusto7. Ovídio segue o conceito de Hesíodo na divisão cronológica da mitologia clássica e une os deuses aos mortais nas descrições sobre o amor, incesto, ciúme e morte. O poeta funde personagens mitológicos gregos com os romanos e aproxima o mito da história, em que os personagens ganham humanidade e se afastam das solenes divindades.

A Mitologia segue produzindo efeitos na imaginação. Os dramas do teatro grego e os mitos da antiguidade são reinterpretados continuamente a partir do período artístico denominado de Renascimento até os estilos chamados de Neoclássico e Romantismo que atravessam o século XIX, proporcionando novo entusiasmo pela cultura clássica, o que inclui necessariamente novos autores reescrevendo sobre os deuses e heróis.

\subsection{A origem dos deuses}

Seguindo a genealogia, o mundo começou com Abismo, a inexistência, o Caos. Do caos nasceu a divindade que personifica a Terra. Em seguida surgiu o Tártaro e Eros o mais belo dos imortais, o desejo.

Os deuses primordiais ${ }^{8}$ geraram inúmeros filhos, mas foi de Céu que se seguiram a segunda, e a terceira geração divina.

\footnotetext{
${ }^{5}$ Origem dos Elementos primitivos e mais importantes do mundo e os seres que descendem deles.

6 Origem de alguns costumes e causa de fatos menores, ou melhor explicado: Por que a montanha é verde, por que as amoras são vermelhas.

7 Caio Júlio César Octaviano (63 a.C.-14 d.C.) foi o primeiro imperador de Roma e patrono das artes.

${ }^{8}$ Escuridão e Nix. Dia e Éter. Céu (Urano para os romanos), Montanhas e Ponto. O gigante Tífon e os Ciclopes. Nereu; Taumatante, Fórcis, Cetó e Euríbia. Os Titãs: Oceano, Ceos, Crio, Hipérion, Jápeto, Teia, Réia, Norma, Memória, Febe, Tetís e, o mais novo, Crono (Saturno para os romanos).
} 
Céu odiava e ocultava no Tártaro todos os filhos. A mãe, constrita e farta de tanta tirania, mostrou aos filhos, talhada a partir de uma pedra dura e cinzenta, uma foice com a qual suplicou vingança. De pronto, o filho mais novo e mais astuto, respondeu, prometendo dar fim à sua dor. Assim, feliz com a resposta, a Terra partiu para a ação, escondendo o filho numa tocaia armado com a foice.

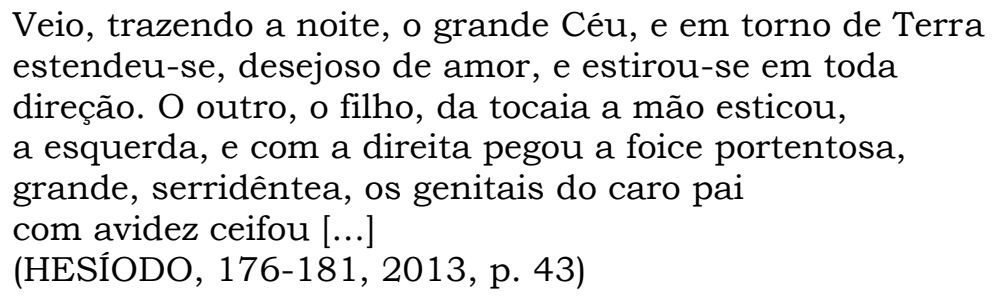

Ao ser castrado, no entanto, Céu avisou a seu filho que ele também seria destronado por um de seus descendentes.

Desse modo, cauteloso, Crono inaugurou a segunda geração ao retirar o poder do velho pai e instaurar o poder dos Titãs sobre o mundo.

Para dar continuidade à linhagem, escolheu sua irmã mais velha, Réia, que gerou Héstia, Deméter, Hera; Hades e Poseidon. No entanto, o deus destinado a ser subjugado, mantinha vigilância cega e engolia os filhos tão logo apareciam, para desespero da esposa.

Quando Réia estava para parir o mais novo e astuto Zeus ${ }^{9}$, suplicou ajuda dos deuses antigos, que planejaram um ardil para enganar o pai devorador, enviando-a a Lictos, uma fértil região da grande ilha de Creta, no Mediterrâneo. Lá chegando, tão logo o filho nasceu, Réia escondeu-o em uma gruta rochosa, coberta por densa floresta.

Quando a negra noite chegou, a vingativa mãe voltou abraçada a uma pedra enrolada em manta, entregando-a ao grande senhor que a devorou rapidamente, sem notar a trapaça.

Em Hesíodo (2013, p. 67) Zeus, mantido a salvo, cumpriu a profecia e destronou Crono com sua força. Em seguida retirou do estômago do pai todos

\footnotetext{
${ }^{9}$ Júpiter para os romanos. 
seus irmãos e libertou os filhos de Céu das profundezas. Em agradecimento ele recebeu o raio flamejante, o trovão e o relâmpago, com os quais governa mortais e imortais.

O filho de Crono depois de derrotar o gigante Tífon, que ameaçava com seus urros destruir o Olimpo, o Oceano e até o Tártaro, dividiu o Universo com seus dois irmãos: Poseidon recebeu o mar, Hades foi para o mundo subterrâneo. Com suas esposas, irmãos e filhos, o deus mais poderoso passou a reinar sobre o mundo, de seu palácio no topo do monte Olimpo, instaurando a terceira linhagem divina.

\footnotetext{
Não se pode lograr nem ultrapassar a mente de Zeus.

Pois nem o filho de Jápeto, o benéfico Prometeu, se esquivou de sua raiva pesada, mas, sob coação, embora mui perspicaz, grande laço o subjuga.

(HESÍODO, 613-616, 2013, p. 75)
}

Zeus, em Teogonia, se torna capaz de articular o mundo dos mortais e imortais, e na mentalidade mítica do povo grego o ser que trata das relações entre deuses e homens. É ele que dita a ordem no universo, controlando as batalhas e as uniões entre imortais e mortais.

Zeus se uniu com diferentes deusas ${ }^{10}$. Com a chegada de Hera, e notando que ela era muito bela e aparentava grande nobreza de espirito, decidiu que a irmã gêmea reinaria ao seu lado. Da união de Zeus e Hera nasceram: Ares, Eilêitia e Hebe, a personificação da juventude.

Tão logo a deusa recebeu parte dos reinos e impérios mostrou que sua nobreza aparente escondia grande sede de perseguição e vingança com quem quer que fosse, principalmente entre as amantes do marido e os filhos bastardos. Enfurecida com o marido, gerou sem a união do amor, Hefesto, que “nas artes supera a todos os Celestes” (HESÍODO, 929, 2013, p. 97).

Por seu lado, Zeus se uniu a outras incontáveis belas mulheres, imortais, semideusas e mortais. Mas, pode-se afirmar que de nenhuma ou de

${ }^{10}$ A primeira esposa foi a deusa da astúcia e da sabedoria, Métis, filha dos titãs Tetís e Oceano. Sob severos conselhos Zeus a engoliu antes da filha nascer. Por isso Atena, terrivel e incansável guerreira, nasceu de sua cabeça. Com a segunda esposa, Norma, gerou as Moiras e as Horas. De Eurinome, nasceram as três Graças. 
qualquer filho Zeus se esqueceu. Todos foram transformados em deuses ou semideuses, ou ficaram conhecidos por seu heroísmo.

Com Memória, de formosos cabelos, Zeus gerou as nove Musas ${ }^{11}$, com muito amor. Hermes nasceu da união com Maia, a filha de Atlas, Dionísio foi gerado por Semele, a filha de Cadmo e Harmonia. Héracles nasceu da união por amor com Alcmena, esposa de Anfitrião. Com a irmã Deméter gerou Perséfone, raptada por Hades, e da união com Leto, de belos cabelos, nasceram Apolo, reconhecido como o sol da geração olímpica e Ártemis, a deusa da lua, "prole desejável mais que todos os Celestes" (HESÍODO, 919, 2013, p. 95).

\section{APOLO - O DEUS SOL}

Figura 1: Guillaume DUPRÉ (ca. 1574-1642) Apolo guiando o carro do sol, 1613. Baixo relevo em bronze (reverso) diâmetro de 7,27x107,8 gr.

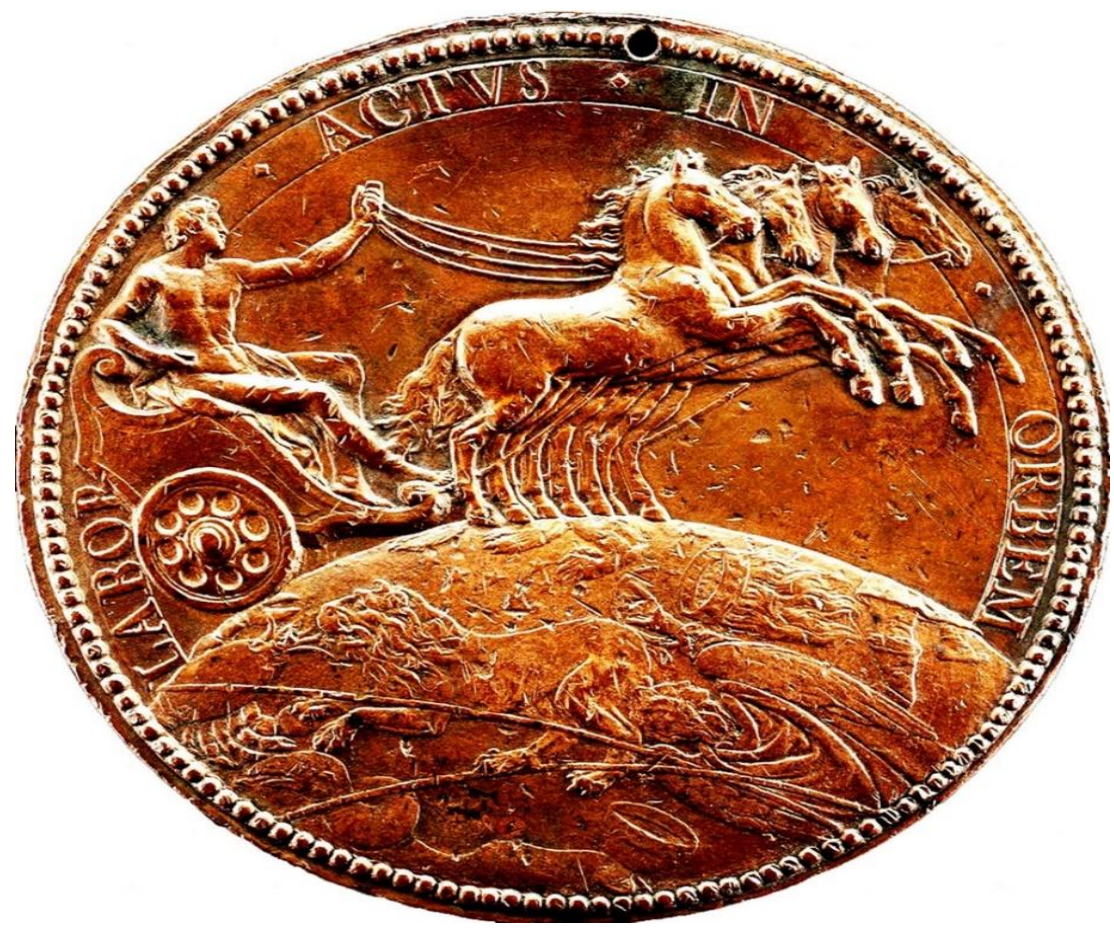

Acervo: National Gallery of Art, Washington D.C., EUA. Division of Imaging and Visual Services. Samuel H. Kress Collection1957. 12 fev. 2018.

11 Os nomes das nove filhas de Zeus com a titânide Memória são: Clio, Euterpe, Tália, Melpômene, Terpsícore, Érato, Polímnia, Urânia e a superior a todas, Calíope, que nasceram para louvar os grandes feitos dos seres divinos. 
O mito de Apolo é um dos mais importantes e conhecidos da Mitologia greco-romana, depois de Zeus. Imperadores e monarcas apreciaram e se utilizaram de seus valores simbólicos, enquanto artistas e poetas destacaram e interpretaram ao longo de séculos sua personalidade complexa, ligada aos aspectos humanos, ligados à sociedade e à natureza.

Apolo é citado e elogiado por Homero, tanto na líada como em Odisseia, sendo um dos personagens mais comentado ao longo dos Cantos. Na líada, o deus flecheiro participa ativamente da disputa entre gregos e troianos, toma partido e defende seus heróis, diverte os outros deuses, cura e protege os corpos dos combatidos.

Menino ainda, Apolo, munido de terriveis flechas, vinga sua mãe, matando a serpente Piton, que a havia perseguido. Em seguida retira a pele da víbora e cobre o assento em que a pitonisa ${ }^{12}$ de Delfos profere seus oráculos.

Com um rosto de beleza radiante e juventude eterna, uma cabeleira loura que despenca em cachos graciosos sobre seus ombros, alto e desembaraçado, com um porte sedutor, Apolo passa a ser reconhecido como o deus da luz ao receber de Hélios ${ }^{13}$ o carro solar guiado por selvagens cavalos de cujas bocas e ventas saem fogo.

Em Ovídio (2017, p. 101-103) sua morada é no Palácio do sol, que imita as chamas e se ergue sobre altas colunas, cujo frontão é de marfim reluzente com dois batentes que brilham como prata. Coberto por púrpura manta, o deus da beleza, da arte, da verdade, das profecias, dos oráculos e da criatividade, senta-se num trono com o brilho das esmeraldas.

Deus da música, da poesia, da eloquência, das artes e notável flecheiro, Apolo é representado na maioria das vezes tocando uma lira de ouro, inventada e outorgada como presente por seu irmão Hermes. Em outras

\footnotetext{
12 Sacerdotisa e profetisa do Templo de Apolo, localizado em Delfos, nas encostas do Monte Parnaso, na Antiga Grécia. O conhecido Templo era considerado o mais belo e rico.

${ }^{13}$ Filho dos titãs Hipérion e Teia, Hélios é irmão de Eos/Aurora e Selene/Luna, a Lua.
} 
situações, Apolo se encontra no Monte Parnaso, localizado próximo à fonte Hipocrene ${ }^{14}$, rodeado pelas nove Musas, protetoras das artes.

O deus de Delos ${ }^{15}$ foi amplamente cultuado em Roma, com o nome de Febo Apolo. A Antiguidade clássica, e artistas dos periodos Renascentista e Barroco mostraram-no como um deus de beleza perfeita, simbolo da harmonia entre corpo e espírito.

Expulso do Olimpo por um período, Apolo foi condenado a viver na terra, ocasião em que ensinou os humanos a arte da música e da dança, tomou conta de rebanhos e, ainda, ajudou Posseidon a construir as muralhas de Tróia, na Frígia.

O mito de Apolo desempenhava dois lados da natureza humana, o bem e o mal. Podia causar o bem trazendo boa fortuna e alegria e quando apaixonado, movia céus e terra por seu amor, ou podia dar origem a desastres, quando enfurecido.

Louvado como deus da agricultura e dos rebanhos, protetor da lei e da ordem e deus das artes e da ciência, Apolo matou muitos com suas flechas mortais, jogando a peste nas planícies de Troia; puniu Midas fazendo crescer nele orelhas de burro; matou, junto com sua irmã, os filhos de Niobe; esfolou vivo Mársias no concurso musical, e guiou a flecha mortal de Páris que atingiu o herói Aquiles no calcanhar, na disputa de Tróia.

\section{APOLO APAIXONADO}

Apolo foi apaixonado e muito amado por mortais e imortais, homens e mulheres, porém, essas relações e os frutos gerados dependem das diferentes versões literárias ao longo do tempo.

\footnotetext{
${ }_{14}$ Nascente de água doce situada na encosta do Monte Hélicon, tradicionalmente consagrada a Apolo/Febo e às Musas, que teria brotado de uma pedra fendida por uma patada do cavalo Pégaso.

15 A ilha de Delos está localizada no centro do grupo de ilhas conhecido como Cíclades, no mar Egeu. Delos foi considerada como santuário de Apolo na Antiguidade Clássica.
} 
Aqui, destacam-se apenas duas de suas inúmeras paixões, descritas em versos por Ovídio, em Metamorfoses.

\subsection{Apolo, Daphne e Cupido}

Figura 2: Giovanni Battista TIEPOLO (1696-1770) Apolo perseguindo Daphne, ca. 1755/1760. Óleo sobre tela, 68,5x87.

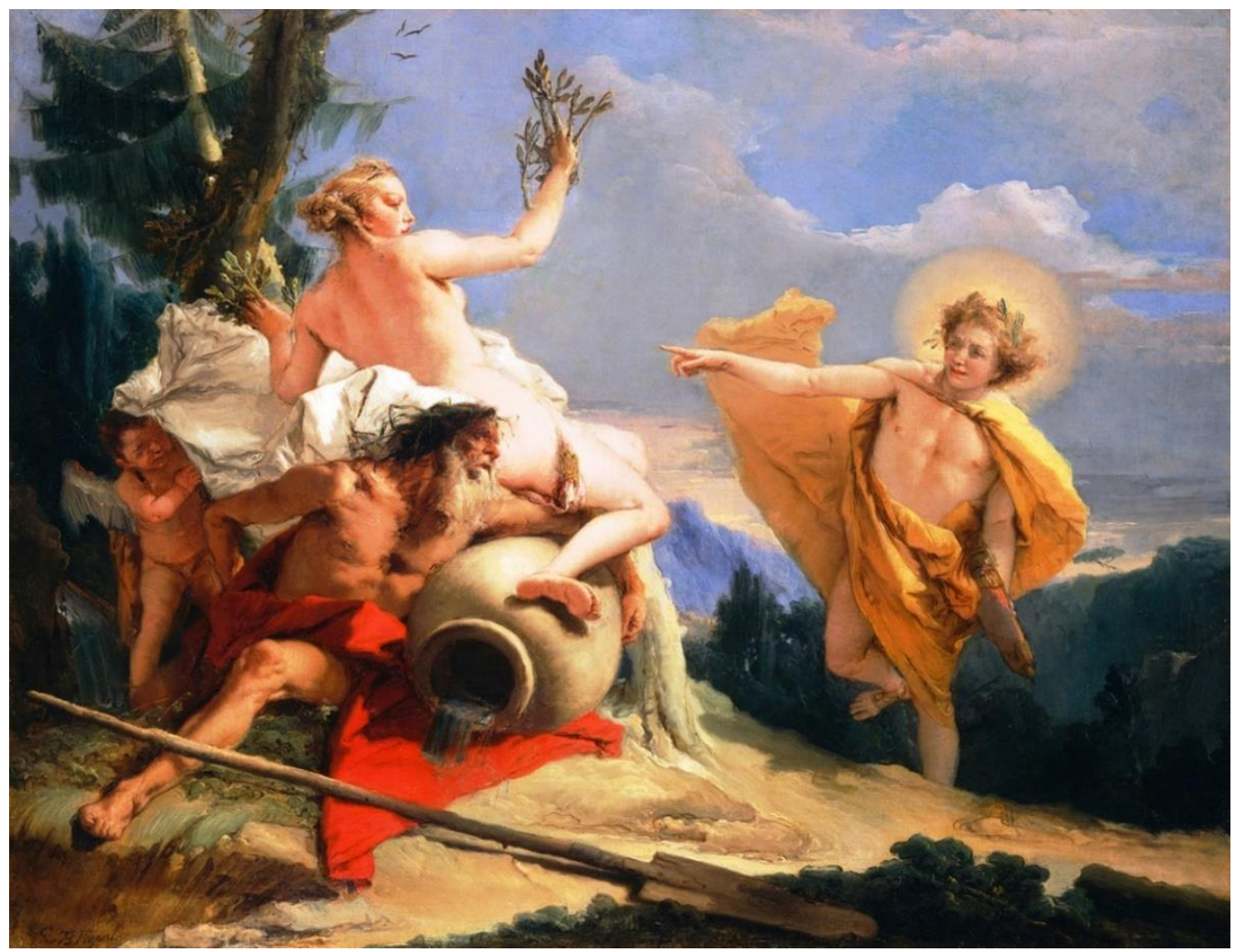

Acervo: National Gallery of Art, Washington, EUA. Division of Imaging, Visual Services. 12 dez. 2017.

Na pintura Apolo perseguindo Daphne, executada por volta de 1755 a 1760, Giovanni Battista Tiepolo (1696-1770), pintor do início do estilo Rococó, em meados do século XVIII, serve-se de consideráveis linhas inclinadas, todas em movimento, para evidenciar o forte impacto dramático e emocional da cena. À direita o jovem Apolo, com o manto amarelo, avança em direção às figuras, da jovem mulher, do idoso pai e do menino, agrupadas à esquerda, descentralizando a composição pictórica. 
Uma forte linha inclinada separa os personagens. O corpo feminino, que parece oscilar sobre o vaso inclinado, se contrapõe à verticalidade de uma só perna fincada no solo da figura masculina. O braço estendido à direita une os personagens e aponta o destino irreversível. Daphne está a ponto de se transformar em árvore, de onde brotarão folhas de loureiro. Na parte inferior, partindo da direita um remo se inclina sobre uma das pernas do velho Peneu, indicando a posição de Cupido, que sorrateiro, se esconde próximo à queda d'água, nas rochas.

Segundo Ovídio (I, 452-453, 2017, p. 77) “o primeiro amor de Febo foi Dafne, filha de Peneu. Esta paixão não foi obra de um cego acaso, mas do violento rancor de Cupido.”

Em uma discussão, Apolo cheio de si por ser exímio flecheiro, involuntariamente ofendeu Cupido, ao comentar sobre suas brincadeiras com o arco e flechas. Desgostoso, o filho de Vênus, cortou o ar com o bater de suas asas, postando-se próximo à uma das árvores do Parnaso.

De sua aljava cheia tira duas setas com funções distintas. Uma afugenta, a outra faz brotar o amor.

A que o faz nascer é dourada, com uma ponta aguda e brilhante. A que o afugenta é romba e tem chumbo no coração da cana. (OVÍDIO, I, 468-471, 2017, p. 77)

Maliciosamente, o erotes do amor acertou uma seta com a ponta de ouro no coração do jovem deus de Delos e a outra com a ponta de chumbo feriu a ninfa Daphne, filha de Peneu, o deus-rio da Tessália.

Rapidamente, o deus-Sol apaixonou-se pela donzela, no entanto, a ninfa percebeu-se apavorada frente à ideia de amar e ser amada.

Apolo Febo, oráculo do mundo todo, não logrou adivinhar seu próprio destino. Apaixonado passou a perseguir a donzela, onde quer que fosse e ela passou a fugir, sem sequer ouvir as súplicas do jovem e as explicações de que ele era um deus, que amava o canto e a lira, filho de Júpiter, senhor de Delfos e amado em Delos. 
A ninfa seguidora da virgem Diana ${ }^{16}$, em resposta ao questionamento do seu pai, que lhe desejava um genro e muitos netos, cobriu-se de vergonha e lançando os braços ao redor do pescoço do pai, suplicou-lhe:

\footnotetext{
"pai querido, que eu perpetuamente goze de minha virgindade. Já antes o pai de Diana lhe consentiu o mesmo."

Ele consentiu, mas não consente a tua elegância que sejas o que pretendes! Com teu voto contende a tua beleza. Febo está apaixonado. Ao ver Dafne, quer unir-se a ela. E o que ele deseja, espera-o. Os próprios oráculos o enganam. (OVÍDIO, I, 486-491, 2017, p. 79)
}

Certo dia, impaciente, desprezado e excitado por Cupido, o jovem deus correu veloz atrás de Daphne, quase alcançando-a. Em pânico a jovem, já quase vencida pelo cansaço, avistou as águas de Tessália, onde o pai sempre repousava. Gritando, suplicou ao deus dos rios que se abrisse a terra para abriga-la ou que a transformasse retirando-lhe a beleza, tão fatal.

Em segundos, seus membros adormeceram; uma casca verdejante cobriu-lhe o peito, as mãos ganharam galhos e folhas.

\footnotetext{
O pé tão veloz ainda agora, fica preso qual forte raiz. A sua cabeça é copa de árvore. Só o brilho nela se mantém. E Febo ainda a ama. Pousando-lhe no tronco a mão, sente ainda o palpitar do coração sob a nova casca. $\mathrm{E}$, abraçando os ramos no lugar dos membros, beija a madeira. Mas ao beijo, a árvore retrai-se. (OVÍDIO, I, 551-556, 2017, p. 83)
}

Desconsolado, certo de que jamais a bela jovem seria sua mulher, o deus jurou para sempre que as folhas do loureiro seriam suas preferidas, continuamente verdes, para enfeitar a lira e sua cabeça, assim como para coroar as frontes dos heróis, nos cortejos triunfais.

\subsection{Apolo e Jacinto}

Apolo era apaixonado pelo jovem Jacinto e o acompanhava em todos as atividades, fossem de trabalho, de diversão ou de caça. Quando junto com o amigo, Apolo Febo esquecia da lira e até de suas flechas.

${ }^{16}$ Ártemis, irmã de Apolo, é chamada pelos romanos de Diana. 
Certo final da tarde, ambos se divertiam junto aos escarpados montes, quando resolveram lançar o amplo disco que carregavam.

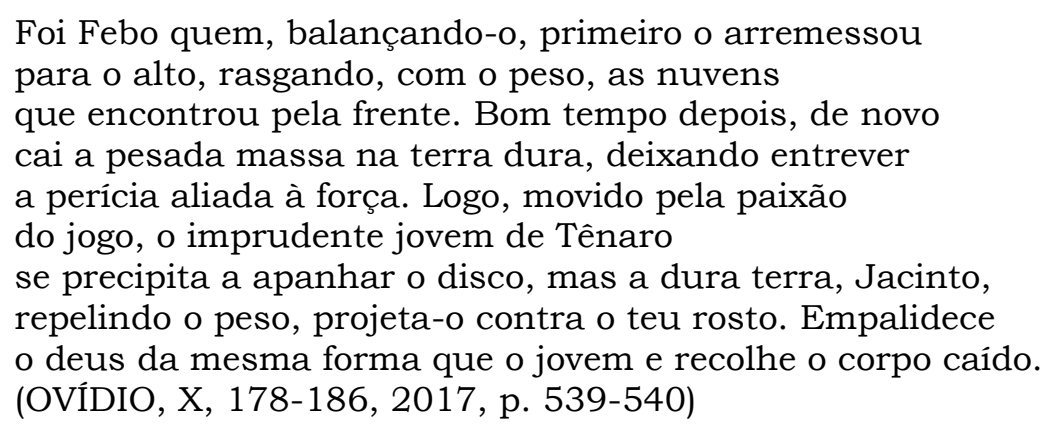

O deus do sol e da música tudo faz para salvar a vida do amigo, mas em vão, a cabeça de Jacinto dobra-se sobre o pescoço, tal como um lírio se dobra sobre a terra quando a haste se quebra.

Em prantos, Apolo deseja que o amigo permaneça junto à memória e aos seus versos cantados ao som da lira tocada por ele. No mesmo instante em que chora Apolo, o sangue que escorre de Jacinto mancha uma erva ali plantada, da qual nasce uma flor. Um lírio, antes branco, cor de prata, mas agora, cor de púrpura. Assim, sempre brota a linda flor, quando a primavera retorna todo ano e Apolo de Jacinto sempre se lembra. 
Figura 3: Nicolas-René JOLLAIN (1732-1804) Jacinto se transformando em flor, ca.1769. Óleo sobre tela, 95x130.

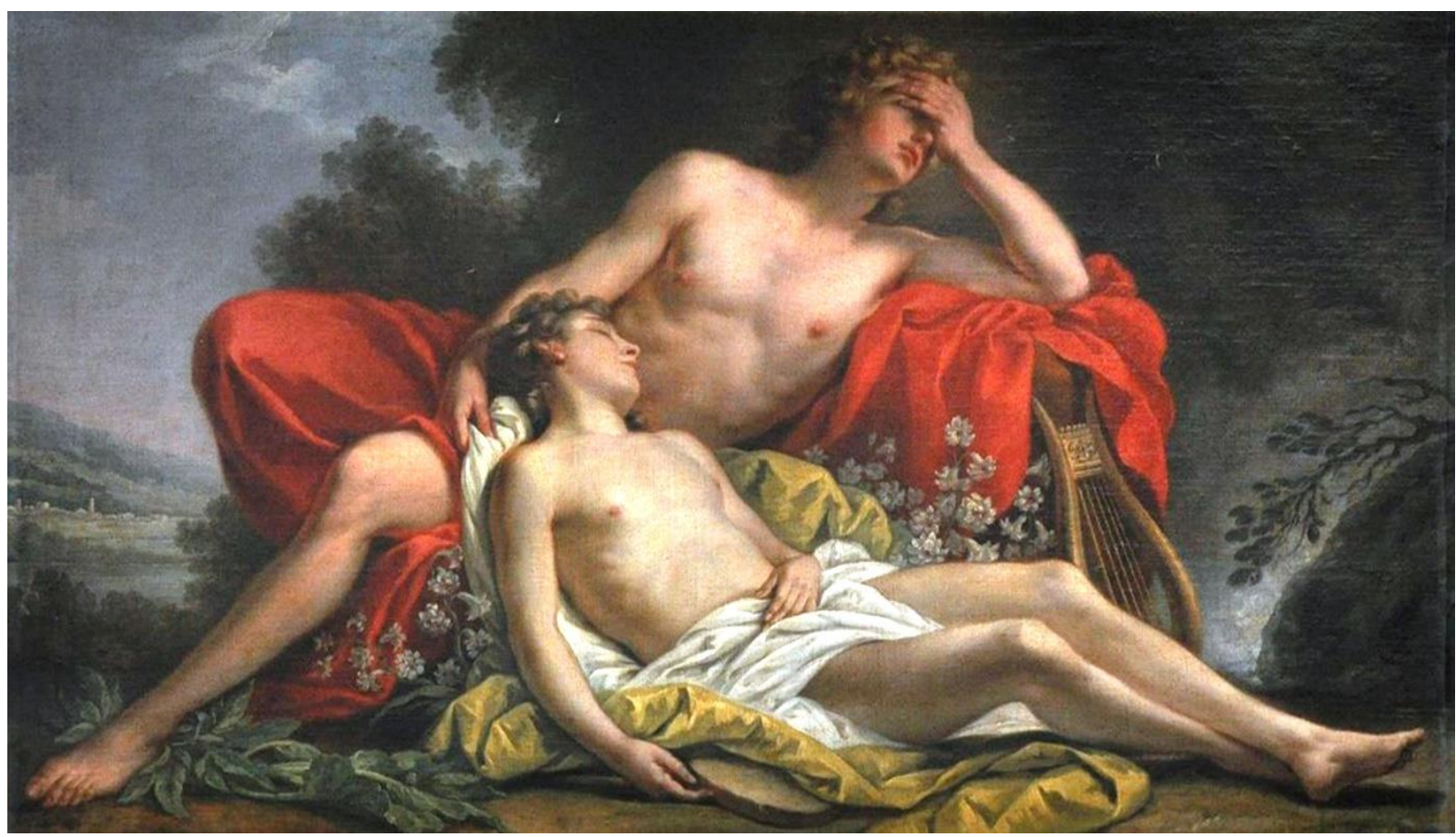

Acervo: Petit Trianon. Photo: (C) Château de Versailles, Dist. RMN / (C Jean-Marc Manaï. França. 20 fev. 2018.

O estilo Rococó está presente na representação do tema de Jacinto se transformando em flor, pintura executada por volta de 1769, por Nicolas-René Jollain (1732-1804), que usa da sensualidade, leveza e graciosidade para definir o documento visual intimista do estilo reconhecido na França com o nome de Luis XV (1710-1774).

\section{APOLO VINGATIVO}

Da mesma maneira, a vingança de Apolo e seus ataques de ira, assim como os ajustes de contas ou a justiça praticada como consequência de atos praticados, são descritos em numerosas fontes. Neste texto as histórias foram priorizadas e apoiadas nos cantos da líada e Odisseia de Homero e nos versos de Metamorfoses de Ovídio. 


\subsection{Apolo atira flechas sobre os gregos}

Figura 4: Jacob MATHAM (1571-1631) Apolo, ca. 1591. Gravura. 33.97x22.54.

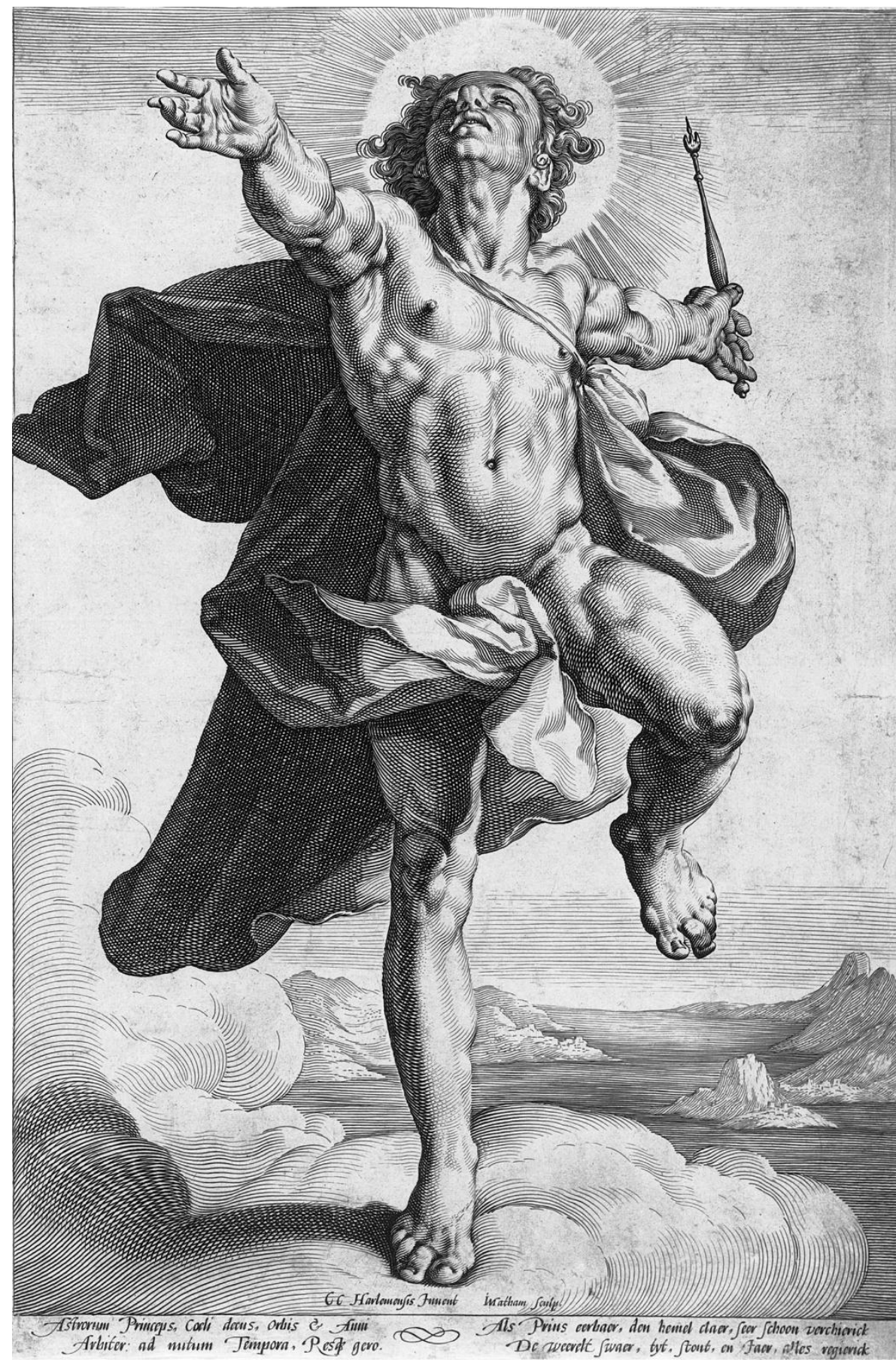

Acervo: Los Angeles County Museum of Art. Los Angeles, EUA. Mary Stansbury Ruiz Bequest (M.88.91.116). Photo (C) Museum Associates/ LACMA. 12 fev. 2018. 
A Iliada, poema épico da literatura ocidental, relata o cerco dos gregos à cidade de Tróia, enquanto comenta a respeito dos deuses do Olimpo ${ }^{17}$, que tomam parte na trama, ajudando diferentes lados, nos cinquenta dias de uma guerra de dez anos. A História da guerra de Troia contada em versos por Homero, trata entre outros assuntos da disputa entre Aquiles e Agamémnon, comandante dos exércitos gregos em Troia. A peste e a ira fazem parte do tema do Canto I, início do poema.

O acampamento de Agamémnon, irmão de Menelau, marido de Helena $^{18}$, recebe a visita de Crises. O sacerdote responsável por cuidar dos templos de Apolo vem para recuperar sua filha que o chefe dos gregos raptara anteriormente.

Insultado, Crises parte de mãos vazias, mas intercede em oração fervorosa a Febo Apolo pedindo vingança. Imediatamente o deus nascido de Leto, indignado, atravessa nos ombros a aljava bem nutrida de flechas e sobe a um dos cumes do Olimpo.

A cada passo que dá, cheio de ira, ressoam-lhe as flechas nos ombros largos; à Noite semelha, que baixa terrivel. Longe das naves se foi assentar, donde as flechas dispara. Do arco de prata começa a irradiar-se um clangor pavoroso. Primeiramente, investiu contra os mulos e os cães velocíssimos; mas, logo após, contra os homens dirige seus dardos pontudos, exterminando-os. Sem pausa, as fogueiras os corpos destruíam. (HOMERO, Miada, I, 46-52, 2015, p. 55-56)

Durante noves longos dias, sobre o exército dos gregos voaram as flechas infaliveis de Apolo. E desceu uma peste sobre os vivos, rapidamente recebidos por Hades.

Ao ver a quantidade de mortos, Aquiles, rei dos Mirmidões ${ }^{19}$, chama Agamémnon que aceita devolver a jovem, mas em troca o herói deve entregar-

\footnotetext{
${ }^{17}$ Apolo, Afrodite, Ares, Leto e Ártemis permaneceram ao lado dos troianos. Zeus e Hades mantiveram-se neutros. As divindades Péon, Íris e Éris também participaram dos eventos. Do lado dos gregos permaneceram: Hera, Atena, Poseidon, Hefesto e Tétis, mãe de Aquiles.

18 Esposa de Minelau, rei de Esparta, Helena ao fugir com Páris, filho do rei de Tróia, ocasionou um movimento de união dos gregos que partiram para derrubar as muralhas de Tróia, ocasionado uma disputa que durou dez longos anos.

19 Seguidores e soldados de Aquiles, na Guerra de Tróia, os Mirmidones pertenciam ao povo tessálico. Dinastia fundada pelo rei Éaco (Filho de Zeus e da ninfa Égina) monarca da ilha de Égina. O rei teve dois filhos: Peleu e Télamo. Aquiles é filho de Peleu e Tétis, uma das cinquenta filhas de Nereu e Dóris, uma das filhas de Oceano.
} 
the a linda escrava Briseide, que vive em sua companhia. Irado, Aquiles rompe com o comandante grego, e se recolhe em sua tenda, saindo da guerra.

Um barco ligeiro parte com a filha de Crises, enquanto os guerreiros gregos se banham para espantar a morte.

Purificaram-se todos, jogando no mar as escórias, e a Febo Apolo ofertaram, de cabras e touros seletos, uma hecatombe completa, na praia do mar incansável. Nas espirais da fumaça até o Céu o perfume subia. (HOMERO, Miada, I, 314-317, 2015, p. 64)

Logo a nau chega ao porto e a filha amada é entregue ao sacerdote, juntamente com inúmeras oferendas ao do deus sol, filho querido de Zeus e Leto.

Crises levando os braços para o alto, clama por Apolo, comandante supremo do seu templo.

Do mesmo modo que ouviste o pedido que fiz no outro dia, e me deste honra, infligindo castigo ao exército Acaio, mais uma vez te suplico atenderes-me ao que ora te peço: livra os Argivos da peste terrivel que as hostes dizima. Isso disse ele na súplica; ouvido por Febo foi logo. (HOMERO, liada, I, 453-457, 2015, p. 67-68)

\subsection{A morte de Aquiles}

Figura 5: Christophe VEYRIER (1637-1689) Aquiles morrendo, 1683. Mármore.
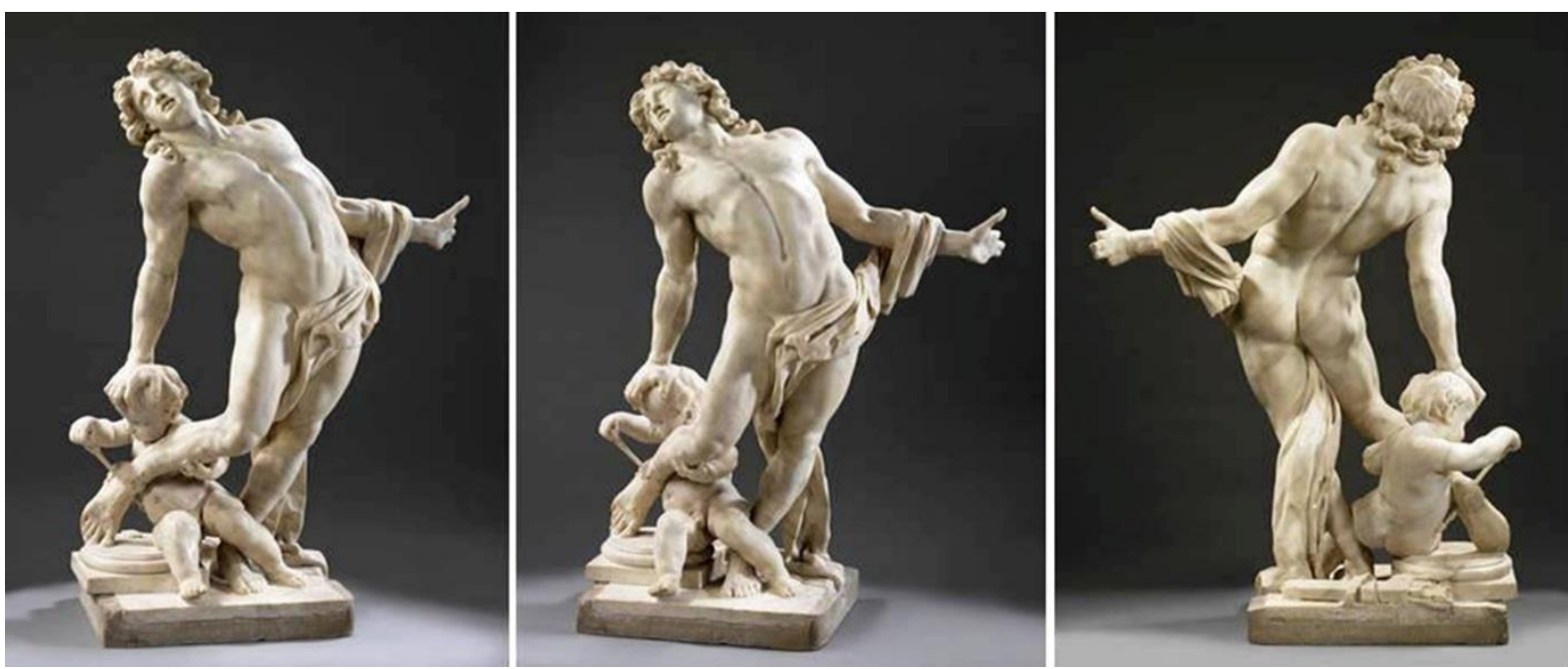

Acervo: Victoria and Albert Museum, Londres, UK. Purchased with funds from the John Webb Trust. 19 fev. 2018. 
A escultura barroca, assinada e datada de 1683, Aquiles morrendo, foi executada por Christophe Veyrier (1637-1689), sobrinho e assistente de Pierre Puget (1620-1694), grande escultor da corte de Luís XIV (1638-1715). A escultura em mármore do herói troiano representado no instante em que a flecha alcança seu calcanhar, foi criada em Toulon, onde Veyrier se estabeleceu, depois de uma estadia em Roma.

Em Iliada, Aquiles que se recusava a participar da disputa entre gregos e troianos, retorna à batalha quando seu amado amigo Pátroclo 20 é morto por Heitor, príncipe de Tróia.

Em busca de vingança, o herói mata Heitor e arrasta seu corpo durante dias ao redor dos muros da cidade, "mas Febo, do herói apiedado, ainda depois da sua morte, o cadáver ampara de todas as ocasiões de estragar-se, cobrindoo com a égide de ouro para que no ato de ser arrastado não viesse a ferir-se" (HOMERO, Miada, XXIV, 18-21, 2015, p. 492).

Aquiles, finalmente, devolve o corpo do príncipe, quando Príamo, suplica por seu filho, no interior de sua tenda, numa noite escura.

A liada termina com as honras e o funeral de Heitor e somente em Odisseia Homero dá conta do destino de tantos e tão grandes heróis. Odisseu, que retorna da guerra, conta mais alguns detalhes do final da disputa entre gregos e troianos, como a história do cavalo de pau e a ruína do povo de Tróia. E no encontro com as sombras dos grandes guerreiros, quando desce ao Hades pela segunda vez, as almas escutam de Agamémnon a história do resgate do corpo de Aquiles.

Quando, afinal, conseguimos tirar-te do campo, no leito te depusemos da nave, e lavamos o corpo bem feito, com água tépida, ungindo-te. Os Dânaos, de todos os lados, as cabeleiras cortavam, em pranto desfeitos, copioso. (HOMERO, Odisseia, XXIV, 43-46, 2015, p. 384)

Após dezessete dias de honras e o choro dos deuses, acompanhados por Tétis, sua mãe, o corpo de Aquiles banhado em óleo e mel foi levado às chamas e queimado com roupas divinas. No dia seguinte, as cinzas brancas se

\footnotetext{
${ }^{20}$ Filho de Menetes, Pátroclo foi criado na corte de Peleu, junto com Aquiles. Os dois amigos lutaram juntos em batalhas anteriores à guerra de Tróia.
} 
misturaram às de Pátroclo e foram transportadas à terra Natal, dentro de uma ânfora de ouro produzida por Hefesto, o deus das forjas.

Contudo, os detalhes da morte de Aquiles se encontram em outras fontes. Uma delas pertence à Metamorfoses, de Ovídio.

Apolo fora obrigado a fechar os olhos durante a luta de Heitor e Aquiles, por ordem de Zeus, que seguia os desígnios do destino, segundo o qual Aquiles morreria após matar o príncipe troiano. Desolado, Apolo conversa com Poseidon, que também está aborrecido por ver as muralhas que os dois ajudaram a levantar prestes a cair. De conversa em conversa, o deus das flechas douradas e envenenadas resolve dar um basta no terrivel herói dos mirmidões.

Nos momentos terriveis em que os gregos invadem Tróia, Aquiles luta ferozmente avançando na bela cidade e matando todos que encontra pela frente. O filho de Príamo protege o palácio prestes a ser invadido, enquanto sua família tenta fugir em busca de abrigo, quando Apolo chega ao local.

\footnotetext{
No meio da carnificina, descobre Páris a desferir alguns dardos sobre aqueus desconhecidos. Dá sinais de que é um deus e adianta: "Por que desperdiças flechas no sangue do povo? Se os teus te preocupam, volta-te para o neto de Éaco.

E vinga os teus irmãos mortos!"

Depois de o informar e lhe mostrar o filho de Peleu que com seu ferro de mão prostrava corpos troianos, volta para este o arco de Páris e, com sua mortífera destra, dispara seta infalivel. (OVÍDIO, XII, 599606, 2017, p. 667)
}

A flecha guiada por Apolo, o vingador, atinge o calcanhar de Aquiles que cai por terra, morrendo logo em seguida. A seta infalivel lançada por Páris, mas guiada por Apolo vinga Heitor e todos os que caíram por terra sob o jugo de Aquiles, o filho de Peleu e Tétis.

\subsection{Apolo e Mársias}

A história faz parte dos castigos que Apolo infringiu aos mortais que se julgaram superiores frente aos seus dons divinos. 
O sátiro Mársias havia encontrado, junto a floresta que habitava, uma flauta, que parecia celestial. Muitos diziam que pertencera à deusa guerreira, Minerva.

Mársias experimentou o instrumento e dele tirou sons nunca antes ouvidos naquela parte da Lícia, tanto que chamou atenção do deus da música, que desceu do monte Parnaso para ouvi-lo. Orgulhoso, o sátiro desafiou o jovem divino a produzir um som mais extraordinário. Os dois adversários combinaram que o vencedor escolheria a pena.

Evidentemente, Mársias perdeu, mesmo porque os árbitros ali presentes não ousariam dizer o contrário. Vencedor, o filho de Leto iniciou o castigo, que se resumia em esfolar vivo o infeliz sátiro.

Gritava ele: "Por que me arrancas de mim mesmo?

Ah! Estou arrependido! Ah! Não vale tanto uma flauta", clamava.

Debaixo de gritos, de todo o corpo lhe é tirada a pele.

Não é senão carne viva. De todo ele goteja sangue.

Ao serem descobertos, os músculos ficam expostos. Sem a pele, trepidantes, as veias latejam. Palpitantes, as entranhas podiam contarse, e contar-se os vasos que brilham no peito.

Choraram-no os faunos do campo, as deidades das florestas, os sátiros, seus irmãos, e também o Olimpo (OVÍDIO, VI, 385-393, 2017, p. 341)

As ninfas e pastores de bois e ovelhas também choraram, espalhados entre montanhas e florestas. Tanto, que a terra fértil se umedeceu, recolhendo as lágrimas em seu interior.

Ao torna-las água, enviou-as para o espaço vazio.

Daí que o mais transparente dos rios da Frígia que, entre abruptas margens, se dirige célere ao violento mar, se chame Mársias.

(OVİDIO, VI, 398-400, 2017, p. 343) 
Figura 6: Girolamo TRÒPPA (1637-1710) Apolo esfolando Mársias, ca. 16511706. Óleo sobre tela, $96 \times 132$

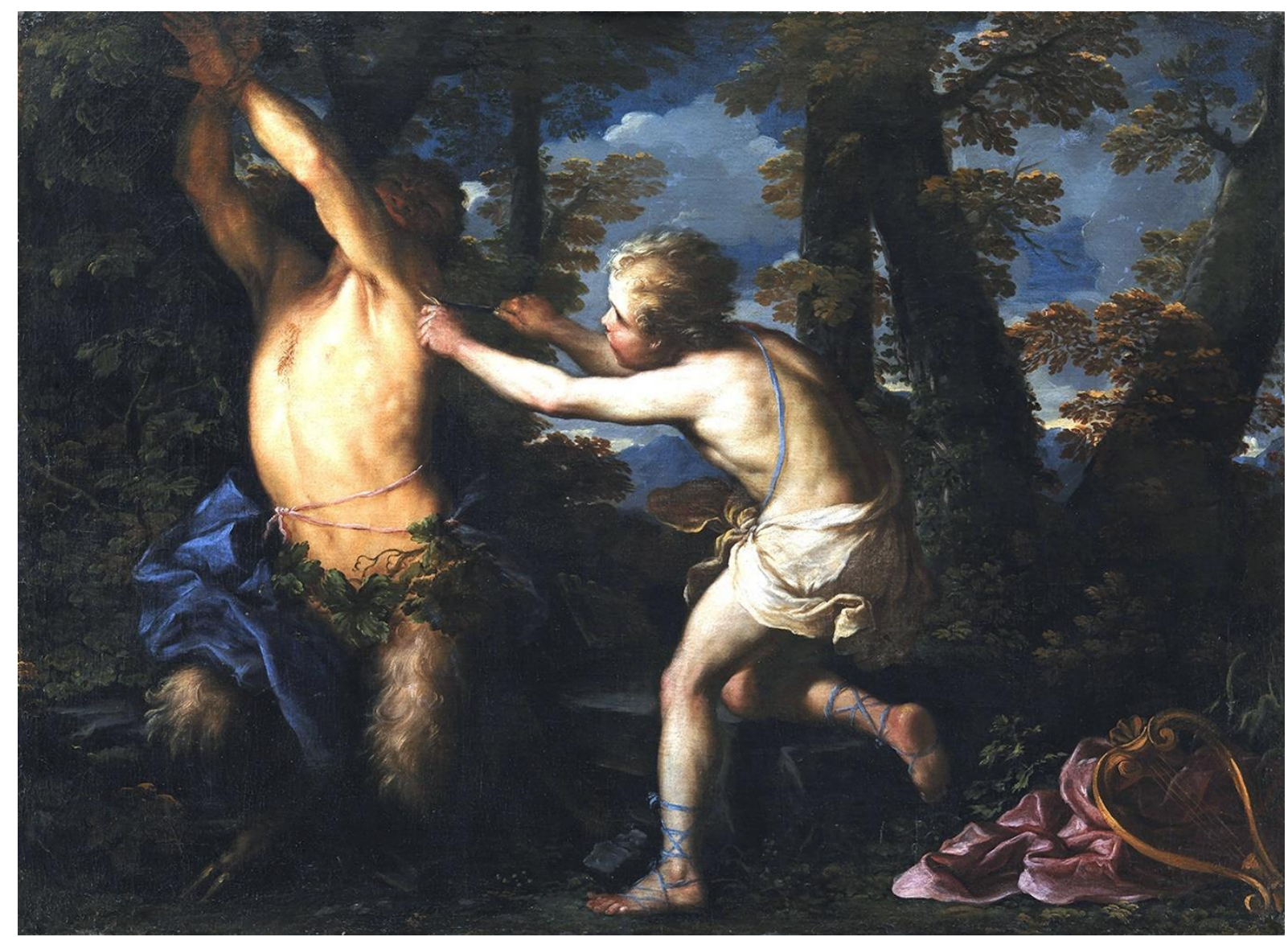

Acervo: Statens Museum for Kunst. Copenhagen, Dinamarca. Public Domain (CCO) SMK Photo/Skou-Hansen/Buccarella. KMSsp123. 13 fev. 2018.

A obra Apolo esfolando Mársias, executada por volta de 1651-1706, por Girolamo Tròppa (1637-1710) apresenta o estilo do Barroco tardio, praticado em Roma, na Itália. Um estilo em que se combina a arte clássica renascentista, aplicada por Rafaelo Sanzio (1483-1520), combinada com o contraste do claro e escuro do grande pintor italiano, Michelangelo Merisi da Caravaggio (15711610).

\subsection{Niobe}

Rainha de Tebas, filha de Tântalo ${ }^{11}$ e parente do gigantesco Atlas, Niobe tinha tudo para se considerar uma mulher feliz: um marido que a amava, um

\footnotetext{
${ }^{21}$ Filho de Zeus/Júpiter e Plota, neto do titã Atlas, por parte da mãe, Tântalo foi castigado e jogado aos Infernos por seu pai, depois de revelar segredos divinos aos homens.
} 
palácio e todo poder procedente dele, e para seu orgulho, catorze saudáveis filhos, gêmeos, sete mulheres e sete homens, todos perfeitos e de rara beleza.

Nem um tanto humilde, a jovem rainha, vestida em ouro e seda foi participar de uma festa em honra a deusa Leto e reclamou em altos brados sobre o excesso de oferendas por parte de seus súditos, que ao contrário deveriam venerar muito mais os membros de sua própria família, também nobres e parentes dos deuses.

Gritando, continuou afirmando que por mais que ocorressem problemas ao seu redor, continuaria abundante e afortunada sua vida, pois ainda que morresse um só filho, ainda assim teria mais filhos que a deusa, que só tinha dois.

Assim, muitos dos crentes abandonam o culto, obedientes, interrompendo as honras à deusa, amada por Júpiter e filha do grande Titã Urano.
A deusa indignou-se e, no ponto mais alto do Cinto, ${ }^{22}$ conversou nestes termos com seus dois filhos:
"Aqui estou eu, a vossa mãe, orgulhosa por vos ter criado, que não sou inferior a nenhuma deusa, com exceção de Juno. Eu duvido se sou deusa, ó meus filhos, e, se vós não me socorrerdes, sou tirada dos altares, ao longo de tantos séculos cultuados. (OVÍDIO, VI, 204-209, 2017, p. 331)

Reclamando da ousadia da rainha, a deusa continuou a descrever seu tormento, mas antes de terminar, seus filhos a interromperam, e em grande velocidade desceram entre as nuvens até às portas da cidade de Cadmo ${ }^{23}$.

$\mathrm{Na}$ planície verdejante, os filhos de Niobe praticavam exercícios. Um a um foram caindo pelas flechas dos irmãos arqueiros, Apolo e Diana.

Aterrorizados o povo tebano correu a chamar os reis, mas só Niobe e as filhas chegaram ao local impregnado de sangue por todos os lados, pois o pai em desespero ao receber a terrivel notícia, deu fim à sua vida.

No entanto, no lugar de pedir perdão à deusa, Niobe bradou aos céus chamando-a de cruel e ainda se orgulhou de continuar com sete filhas.

\footnotetext{
22 Monte da ilha de Delos.

23 Reconhecido herói fundador da cidade grega de Tebas, casado com Harmonia, filha de Ares/Marte e Afrodite/Vênus. O casal, no fim da vida, foi transformado em serpentes.
} 
Mal terminou de gritar, as jovens se agarraram umas às outras vencidas pelas setas certeiras.

Restou só Niobe petrificada pelo sofrimento. Todos ao seu redor perderam a vida.

Até a própria língua gela dentro do duro palato.

$\mathrm{E}$ as veias deixam de poder mover-se. Seu pescoço não pode flectir, os braços fazer movimento, nem seus pés podem andar.

Também as suas entranhas se mudam em pedra.

Apesar de tudo, chora! E, envolta no turbilhão de um vento forte, é transladada para a sua terra. Colocada aí, no cimo de um monte, ela jorra água, e mesmo o mármore derrama ainda lágrimas.

(OVÍDIO, VI, 306-312, 2017, p. 337).

Figura 7: Abraham BLOEMAERT (1566-1651) Apolo e Diana punindo Niobe com a morte de seus filhos, 1591 . Óleo sobre tela, 203x249,5. 


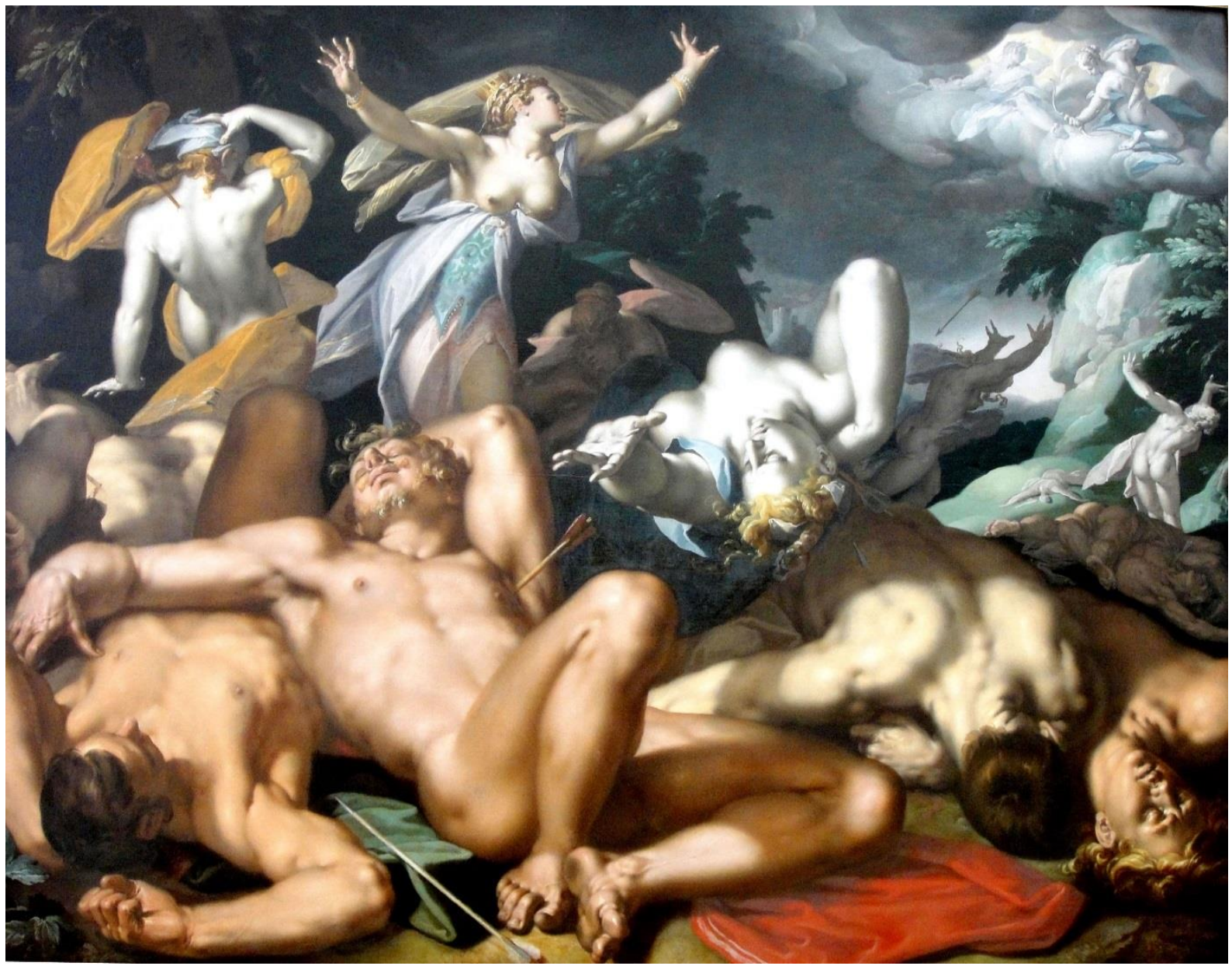

Acervo: Statens Museum for Kunst, Copenhagen, Dinamarca. Public Domain (CCO) kmssp342. 11 dez. 2017.

A composição de Abraham Bloemaert (1566-1651) Apolo e Diana punindo Niobe com a morte de seus filhos, executada em 1591, no estilo Maneirista, apresenta a história de Niobe e a morte de seus catorze filhos.

O posicionamento dos personagens, em posturas intrincadas, e ângulos intensos, entremeados de jogos de luz e sombra, apontam para o estilo do final do século XVI.

Os catorze personagens feridos por flechas, alguns mortos, outros prestes a dar os últimos suspiros, se entrelaçam e se contorcem ao redor da mulher que levanta os braços em súplica.

Os elementos dispostos fundem-se um nos outros de forma a se constituir em um só movimento generalizado e dinâmico. 
Os corpos mais ao fundo, remetem ao estilo Maneirista, com formas que lembram as antigas estátuas clássicas, congeladas no tempo. Mas, as quatro figuras dispostas na frente, já possuem características que espelham o estilo Barroco, inclusive nas formas abertas, que ultrapassam o plano pictórico.

Não existem linhas horizontais e verticais, mas uma sucessão de linhas inclinadas que se repetem alternadamente entre as figuras e flechas dispostas ao longo de toda composição.

Sem planos definidos, a escala das figuras vai se reduzindo até chegar aos dois personagens, entre as nuvens, no canto superior à direita.

\subsection{Apolo versus Pã e o Castigo de Midas}

Midas após ser punido por sua ganância ${ }^{24}$ vivia perambulando pelos campos, longe de seu antigo reino e cultuando Pã, o deus dos bosques e dos rebanhos.

Nessas andanças encontrou-se numa determinada inclinação de duas pequenas montanhas, em que se deparou com Apolo e Pã que ajustavam uma disputa, tendo como árbitro o deus das montanhas, o velho Tmolo.

Pã fazia alarde junto das suas amigas ninfas, sobre o som que sua flauta de canas produzia e ousara desdenhar da música de Apolo.

Assim, o velho juiz sentado sobre um monte, se preparou para ouvir a melodia dos dois deuses.

\footnotetext{
Pã faz soar sua rústica flauta e, com seu rude canto, encanta Midas, ocasionalmente presente junto a si. A seguir, o sagrado Tmolo volta sua face para a face de Febo. A floresta segue o seu olhar. Com a loura cabeça cingida de louro do Parnaso, varre Febo o chão com o manto tingido com a púrpura de Tiro. Na mão esquerda, incrustada de gemas e marfim da Îndia, sustenta a lira, na outra impunha o plectro. Sua pose era de artista. Com seu hábil polegar, Faz então vibrar as cordas. Fascinado com aquela suavidade, O Tmolo convida Pã a submeter a cana à cítara. (OVÍDIO, XI, 162-171, 2017, p. 587)
}

\footnotetext{
${ }^{24}$ Recompensado por Baco, Midas, rei da Frígia, recebeu o dom de transformar em ouro tudo que tocava. Porém, desesperado e arrependido por não poder se alimentar ou beber, pois tudo virava barras douradas, foi perdoado pelo deus do vinho e voltou a vida normal.
} 
Todos concordaram com a escolha do velho. Menos Midas, para surpresa de Apolo, que na mesma hora transformou os ouvidos do antigo rei em grandes orelhas de burro, molengas e cobertas de pelos por dentro e por fora.

Horrorizado com a transformação, Midas cobriu-as com um gorro vermelho e foi se embora, envergonhado.

Pouco tempo depois, seu servo ao lhe cortar os cabelos, descobriu as enormes orelhas. Ansioso por desvendar o segredo e a desonra do antigo rei, afastou-se para o campo, abriu um buraco no chão e contou o segredo, tampando-o logo em seguida.

Espesso tufo de trêmulas canas começa a brotar ali e, logo que, passado um ano, atinge a maturação, atraiçoa aquele que as semeou.

De fato, agitado por um suave Austro, repete a palavra ouvida e denuncia as orelhas de seu senhor. (OVİDIO, XI, 162-171, 2017, p. 587)

Figura 8: Jan van den HOECKE (1611-1651) O julgamento de Midas, 1640. Óleo sobre painel. $73,66 \times 103,51$.

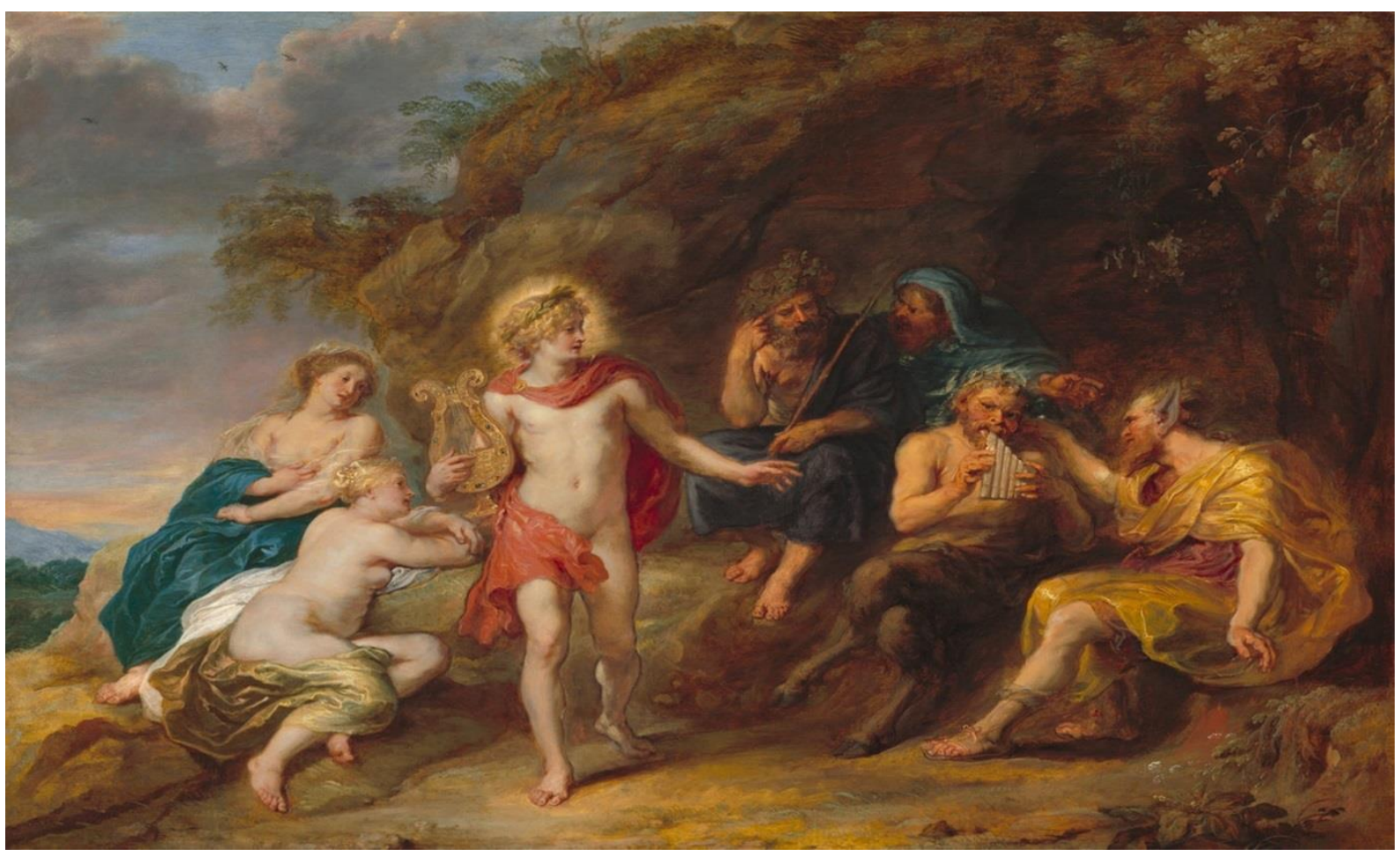

Interfaces da Educ., Paranaíba, v.9, n.25, p. 423-451, 2018. 
Acervo: National Gallery of Art, Washington, D.C. EUA. William A. Clark Collection. 2015.143.18. A43294. 12 fev. 2018.

Jan van den Hoecke (1611-1651) foi aluno de Peter Paul Rubens (15771640), um dos mais famosos artistas flamengos do estilo Barroco, no século XVII. As figuras com cabelos encaracolados, nariz pequeno e pontiagudo e, olhos ligeiramente grandes para o tamanho do rosto, são características do estilo praticado por Hoecke, na série de composições com temas mitológicos.

A pintura no estilo Barroco, O julgamento de Midas, executada em 1640, apresenta Apollo com uma capa esvoaçante vermelha. Sentados estão Tmolo e um companheiro, Pã e Midas com capa amarela.

No lado esquerdo, duas ninfas observam o deus da música que carrega a cítara dourada. Orgulhoso, o deus dos pastores e rebanhos sopra nos tubos de cana e foge do olhar de Apolo triunfante, com a coroa de louro.

A composição mostra Pã ainda tocando, porém, Midas já apresenta as orelhas de burro.

\section{CONSIDERAÇÕES FINAIS}

O texto apresentado escolheu excertos da literatura mitológica, especificamente as histórias sobre o deus sol, o Belo Apolo, com suas paixões e represálias, reunindo as representações simbólicas às Artes visuais.

A redescoberta da Antiguidade Clássica no Renascimento consolida-se e estende-se até o século XIX, no período denominado de Neoclássico, principalmente pela interpretação e reinterpretação sucessiva da literatura greco-romana aplicada às artes visuais, que perpassa pelo naturalismo e fidelidade na representação da natureza, nesses movimentos artísticos.

Espera-se que por meio dos poemas mitológicos de Homero, Hesíodo e Ovídio, escritos tão longe no tempo, mas atuais na memória e na literatura, interligados às pinturas, gravuras e esculturas expostas aqui, o observador compreenda o tema e o propósito artístico das obras produzidas, nos diferentes estilos, vinculadas às histórias sobre os deuses, heróis e 
personagens clássicos e, induza-o à uma nova e diversa atitude cultural na apreciação das obras de arte, seja na Literatura, seja nas Artes visuais.

\section{REFERÊNCIAS}

BRANDÃO, Junito de Souza. Mitologia Grega. Volume I. Petrópolis: Vozes, 1986. 419p

. Mitologia Grega. Volume II. Petrópolis: Vozes, 1987. 383p.

. Mitologia Grega. Volume III. Petrópolis: Vozes, 1987. 419p.

BULFINCH, Thomas. O Livro de Ouro da Mitologia: (a idade da fábula): História de deuses e heróis. Tradução David Jardim Junior. 26. ed. Rio de Janeiro: Ediouro, 2002. 419p.

CASSIRER, Ernest. Linguagem e Mito. Tradução J. Guinsburg. 4. edi. São Paulo: Perspectiva, 2013. 128p.

COMMELIN, P. M. Mitologia grega e romana. Tradução Eduardo Brandão. 3. ed. São Paulo: Martins Fontes, 2008. 433p.

FRANCHINI, A. S.; SEGANFREDO, Carmen. As 100 melhores histórias da mitologia: deuses, heróis, monstros e guerras da tradição greco-romana. 9. ed. Porto Alegre: L\&PM, 2007. 482p.

GOMBRICH, E. H. A História da Arte. 16. ed. Rio de Janeiro: LTC, 1999. 505 p.

HESÍODO. Teogonia. Organização e tradução Christian Werner. São Paulo: Hedra, 2013. 103p.

Teogonia e Trabalhos e Dias. Tradução e introdução Sueli Maria de Regino. São Paulo: Martin Claret, 2014. 153p.

HOMERO. Iliada. Tradução e prefácio de Frederico Lourenço. São Paulo: Penguin \& Companhia das Letras, 2017. 715p.

Míada. Tradução e introdução de Carlos Alberto Nunes. Rio de Janeiro: Nova Fronteira, 2015. 536p.

- Odisseia. Tradução e prefácio de Carlos Alberto Nunes. Rio de

Janeiro: Nova Fronteira, 2015. 424p.

JANSON H. W. História da Arte. São Paulo: Martins Fontes, 1992. 823 p.

MENARD, René. Mitologia Greco-romana. Livro III. Tradução Aldo Della Nina. São Paulo: Opus editora, 1991. p. 139

OVIDIO. Metamorfoses. Tradução Domingos Lucas Dias. São Paulo: Editora 34, 2017. 909 p. 